\title{
Effect of dihydropyrimidine derivatives on kinetic parameters of E.carotovora L-asparaginase
}

\author{
Warangkar S.C. ${ }^{1}$, Khobragade C.N. ${ }^{1 *}$, Dawane B.S. ${ }^{2}$ and Bhosale R.B. ${ }^{2}$ \\ ${ }^{1 *}$ School of Life Sciences, Biotechnology Research Laboratory, Swami Ramanand Teerth \\ Marathwada University, Nanded, 431606 India, e-mail: suchitawarangkar@gmail.com, \\ cnkhobragade@rediffmail.com \\ ${ }^{2}$ Organic Chemistry Research Laboratory, Yashwant Mahavidyalaya, Nanded, 431604, India
}

\begin{abstract}
Purified L-asparaginase in combination with other anticancer drugs like pyrimidine derivatives is administered usually in the body to treat ALL. In the present study, L-asparaginase was purified from Erwinia carotovora up to 247.6 fold and its catalytic properties were studied in the presence of eight different dihydropyrimidine (DHP) derivatives, out of eight derivatives only two viz 4- (2'-hydroxy phenyl) -6- methyl -2- thioxo)-1 - N - benzilydene - 1, 4 - dihydropyrimidine - 5 carboxylic acid ethyl ester $\left(\mathrm{P}_{1}\right)$ and 4 -(2'-hydroxy-5'-chlorophenyl)-5-acetyl-6-methyl-2 pyrimidinone $\left(\mathrm{P}_{2}\right)$ were found to be activators of $\mathrm{L}$-asparaginase. Their catalytic effect was assayed at optimum $\mathrm{pH}$ 8.6 and at temperature $35^{\circ} \mathrm{C}$ in the absence and presence of derivatives $\mathrm{P}_{1}$ and $\mathrm{P}_{2}(20-40 \mu \mathrm{M})$ at $0.02-$ $0.1 \mathrm{mM}$ concentration of asparagine. It was found that derivatives below the concentration $5 \mu \mathrm{g} / \mathrm{ml}$ have no effect on the activity. Derivative $P_{1}$ is found to be a strong activator of the asparaginase activity that was reflected by an increase in the $V_{\max }$ ( 1.75 fold by $P_{1}$ and 2.80 fold by $P_{2}$ respectively) and decrease in the $K_{m}$ ( 0.91 fold by $P_{1}$ and 0.81 fold by $P_{2}$ respectively). The activation of asparaginase is explained by suppressing the cooperativity for the substrate, producing hyperbolic kinetics with $\mathrm{Km}$ of $0.080 \mathrm{mM}$ and by 3 fold increase in the $\mathrm{V}_{\max }$ of the enzyme. The activation by derivative $P_{1}$ and $P_{2}$ were additive, at optimal or suboptimal concentrations of both activators (up to 30 $\mu \mathrm{g} / \mathrm{ml}$ ). The DHP derivatives were further analyzed for quantitative SAR study (QSAR) by using PASS, online software to determine their $\mathrm{Pa}$ value. Toxicity and drug relevant properties were analyzed by PALLAS software in terms of their molecular weight and $\log p$ values. The results showed both the derivatives $P_{1}$ and $P_{2}$ are positive modulators of asparaginase activity and may support the development of novel combination therapy for the treatment of Leukemia and solid blood tumors.
\end{abstract}

Key words: Erwinia carotovora, L- asparaginase, dihydropyrimidine derivatives, activation, cooperativity

\section{Introduction}

L-asparaginase (L-asparagine amino hydrolase, E.C.3.5.1.1) catalyzes the hydrolysis of L-asparagine into L-aspartic acid and ammonia [1-5]. L-asparagine is an essential amino acid for the growth of tumor cells, while the growth of normal cells is not dependant on its requirement. The presence of L-asparaginase deprives the tumor cells from an important growth factor asparagine and therefore they fail to survive. Cleavage of external asparagine may block protein synthesis in the leukemic cells and thereby causes apoptosis of tumor cells [6-9]. Thus Lasparaginase has been a clinically acceptable anti tumor agent for the effective treatment of acute lymphoblastic leukemia (ALL) and lymph sarcoma $[10,11]$. However, it has been reported that clinical employment of bacterial asparaginase is accompanied by the development of side effects. Besides minor side effects such as an allergic reaction and vomiting, L-asparaginase therapy of ALL has some serious side effects. Hypersensitivity reactions to chemotherapeutic antineoplastic agents such as L-asparaginase are most common [12], with many other unusual complications of neutropenia [13], tubular and glomerular dysfunction [14], drug induced pancreatitis [15], acute hepatic dysfunctions [16], cerebral thrombotic complications [17], growth hormone deficiency [18] and deficiency of antithrombin [19]. Therefore, the treatment protocols of ALL and lymph sarcoma do not employ only L-asparaginase as a single agent; instead, it is always a part of multiple agent regimens and combined with drugs having definitive immunosuppressive effects [20].An immunosuppressive agent prevents the immune system from reaction with appearance of foreign protein (asparaginase) in patients' blood circulation [21]. Although the asparaginase has been found in number of organisms like serum of guinea pig and rodents, chicken liver, yeast, molds, plants and number of bacteria, not all of these enzymes are clinically active [22]. L-asparaginase from $E$. coli and E. chrysanthemii has been used as 
chemotherapeutics in ALL for the past three decades [23, 24]. However recent discoveries have indicated that the L-asparaginase from $E$. carotovora is more efficient and exhibits fewer side effects as compared to L-asparaginase obtained from E. coli and E. chrysanthemii [25]. Pyrimidine molecules, which comprises an integral part of nucleic acids now a days are of special importance in medicinal chemistry and received considerable attention because of their diversified activities such as potential antihypertensive agents [26] antiviral [27], antitumor [28], antibacterial agents [29] and immunosuppressive agents [30]. The broad spectrum biological activities of DHP derivatives are depends upon the stereochemistry between the aryl group and DHP ring [31]. It is proposed that Lasparaginase in chemotherapy regimen should have high affinity towards the substrate asparagine and selectively deprives the tumor cells [32].

The diversified activities of DHP derivatives specially antitumor and antileukemic properties of asparaginase prompted us to synthesize different pyrimidine derivatives, to extract and purify $E$. carotovora Lasparaginase and to study its catalytic activity in absence and presence of 4- (2'-hydroxy phenyl)-6-methyl-2- thioxo)-1 - $\mathrm{N}$ - benzilydene 1, 4 - dihydropyrimidine - 5 -carboxylic acid ethyl ester $\left(P_{1}\right)$ and 4-(2'-hydroxy-5'chlorophenyl)-5-acetyl-6-methyl-2-

pyrimidinone $\left(\mathrm{P}_{2}\right)$, the dihydropyrimidine derivatives.

\section{Materials and methods}

\section{Materials}

All the chemicals were purchased from $\mathrm{Hi}$ Media Laboratories (Mumbai, India). All other reagents used were of analytical grade and used without further purification unless stated otherwise.

\section{Enzyme production and partial purification}

Asparaginase (E.C.3.5.1.1) was obtained from E. carotovora (M.T.C.C.1428) by fermentation [33] and purified according to method of Kawaga et.al. [34]. Protein was measured by the Bradford dye binding method using bovine serum albumin as the standard [35]

\section{Molecular weight determination}

Sodium dodecyl sulfate polyacrylamide gel electrophoresis (SDS-PAGE) was carried out in $3 \mathrm{~mm}$ slab gel of $6 \%$ acryl amide in a tris borate buffer $\mathrm{pH} 7.2$ containing $0.1 \%$ SDS. The gels were stained with $0.025 \%$ coomassie brilliant blue R-250 and destained by $1.0 \%$ acetic acid solution. phosphorylase $b$ (97.3kDa), bovine serum albumin (66 kDa), ovalbumin (43 kDa), soyabean trypsin inhibitor (20 kDa), and lysozyme (14.3 kDa) were used as molecular weight markers [36].

\section{Chemistry of $P_{1}$ and $P_{2}$ dihydropyrimidine derivatives}

The synthesis of dihydropyrimidine derivatives $P_{1}$ and $P_{2}$ have already been reported elsewhere [37, 38]. A mixture of Urea/ thiourea / thiurea derivatives (0.I M), acetyl acetone/ Ethyl acetoacetate (0.I M) and substituted aromatic aldehyde $(0.1 \mathrm{M})$ in methanol $(25 \mathrm{ml})$ and catalytic amount of piperidine was added to the mixture and refluxed for $3 \mathrm{~h}$. The contents were kept for refrigeration for overnight. The solid separated out was filtered and recrystallized from proper solvent.

Melting points of the dihydropyrimidine derivatives $P_{1}$ and $P_{2}$ were recorded on an Electro thermal digital melting point apparatus and were uncorrected. IR spectra were obtained on a Nicollet FTIR 500 Spectrophotometer using $\mathrm{KBr}$ pellets. ${ }^{1} \mathrm{H}$ NMR (400 MHZ) spectra were recorded on Bruker Avance Spectrometer in DMSO $d_{6}{ }^{-}$. Chemical shifts were recorded in

$\delta$ ppm with reference to TMS as an internal standard.

\section{Protein Measurements and L-asparaginase assay}

A $0.1 \mathrm{ml}$ sample of purified enzyme solution, $0.9 \mathrm{ml}$ of $0.1 \mathrm{M}$ sodium borate buffer $(\mathrm{pH} 8.5)$ and $1 \mathrm{ml}$ of $0.04 \mathrm{M}$ L-asparagine solutions were combined and incubated for $10 \mathrm{~min}$ at 37 ${ }^{\circ} \mathrm{C}$. The reaction was terminated by the addition of $0.5 \mathrm{ml}$ of $15 \%$ tri chloro acetic acid. After centrifugation, $0.2 \mathrm{ml}$ supernatant was diluted to $8 \mathrm{ml}$ with distilled water, treated with $1.0 \mathrm{ml}$ of Nessler's reagent and $1.0 \mathrm{ml}$ of $2.0 \mathrm{M}$ $\mathrm{NaOH}$. The color reaction was allowed to proceed for $15 \mathrm{~min}$ before the absorbance at $500 \mathrm{~nm}$ was determined. The absorbance was then compared to a standard curve prepared from solutions of ammonium sulfate as the ammonia source [39]. One international unit of L-asparaginase is the amount of enzyme which liberates $1 \mu$ mole of ammonia in $1 \mathrm{~min}$ at $37^{\circ} \mathrm{C}[40]$. The protein content of the enzyme was made on whole cell suspension or crude enzyme preparations from the calibration curve of bovine serum albumin by the standard method [41].

\section{Determination of kinetic parameters}

The $\mathrm{K}_{m}$ and $\mathrm{V}_{\max }$ values were determined in the presence and absence of DHP derivatives $(20-40 \mu \mathrm{g} / \mathrm{ml})$ at $0.10-0.50 \mathrm{mM}$ asparagine 
concentration. The $\mathrm{K}_{m}$ and $\mathrm{V}_{\max }$ values were obtained from Lineweaver double reciprocal plot [42].

\section{Reaction Mechanism of L-asparaginase}

The precise mechanism of L-asparaginase is still unknown although the hydrolysis (figure 1) is known to proceed via a beta acyl intermediate [43].

\section{Proposed Mechanism of interaction of DHP derivative $P_{1}$ and $P_{2}$ with asparaginase}

Both the derivatives interacts with the reactive functional groups of enzymes, DHP derivative $\mathrm{P}_{1}$ with $-\mathrm{COOC}_{2} \mathrm{H}_{5}$ (ethyl ester) (scheme 1) and $\mathrm{P}_{2}$ with $-\mathrm{COCH}_{3}$ (acetyl) group (scheme 2) may be coupled covalently to a reactive group of asparaginase especially lysine residues or the $\mathrm{N}$ terminal of amino group in proteins under conditions of mild $\mathrm{pH}$ and temperature to yield the imine derivative of $P_{1}$ and $P_{2}$ (Scheme 3 and 4).

\section{Drug prediction Analysis}

All the computational work was performed using the BioMed Cache, molecular designing and modeling tool developed for Microsoft operating system developed for Microsoft operating system. Pharmacological activities of DHP derivatives were developed by QSAR study using PASS (Prediction of Activity Spectrum for Substance) online software. It is used to determine $\mathrm{Pa}$ values. Osiris Property explorer an organic chemistry portal was used for evaluation of toxicity and drug relevant properties of DHP derivatives. While PALLAS, a computer tool was used for studying molecular weight, total Hydrogen Bond Donor count (HBD) and Hydrogen bond Acceptor count (HBA). The Log $P$ values were calculated and studied according to the Lipinski rule of 5 in the form of Lipinski score.

\section{Results and discussions}

The synthesized DHP derivatives were characterized by IR and NMR spectral analysis.

4-(2'-Hydroxy phenyl) - 6 -methyl - 2- thioxo-1$\mathrm{N}$ - benzilydene - 1, 4 -dihydropyrimidine - 5 carboxylic acid ethyl ester $\left(P_{1}\right)$ M .P. $217^{\circ} \mathrm{C}$, yield $85 \%$. (Scheme 1)

IR $\left(\mathrm{KBr}, \quad \mathrm{V}_{\max }, \mathrm{cm}^{-1}\right): 3340,3210$, 1730,1595, 1480,1115,1182,1080.

$1 \mathrm{H}$ NMR (DMSO- $\left.\mathrm{d}_{6}\right): 9.8\left(\mathrm{~s}, 1 \mathrm{H}, \quad \mathrm{NH}, \mathrm{D}_{2} \mathrm{O}\right.$ exchangeable ) $7.45-7.90(\mathrm{~m}, 9 \mathrm{H}, \mathrm{Ar}-\mathrm{H})$, $9.30(\mathrm{~s}, 1 \mathrm{H}, \mathrm{N}=\mathrm{C}-\mathrm{H}), 2.15\left(\mathrm{~s}, 3 \mathrm{H}, \mathrm{CH}_{3}\right), 4.10$ (q, $\left.2 \mathrm{H},-\mathrm{COOCH}_{2} \mathrm{CH}_{3}\right), 3.95\left(\mathrm{t}, 3 \mathrm{H},-\mathrm{COOCH}_{2}\right.$ $\left.\mathrm{CH}_{3}\right), 5.15$ (s, 1H,4-C-H), 10.50 (s, $1 \mathrm{H}, \mathrm{OH}$, $\mathrm{D}_{2} \mathrm{O}$ exchangeable).
4-(2'- Hydroxy -5'- chlorophenyl) - 5 - acetyl -6 - methyl - 2- pyrimidinone $\left(\mathrm{P}_{2}\right)$

M.P $=204^{\circ} \mathrm{C}$, yield $80 \%$ (Scheme 2)

IR $\left(\mathrm{KBr}, \mathrm{V}_{\max }, \mathrm{cm}^{-1}\right) 3360,3206,3065,1685$ 1665, 1495, 1090.

$1 \mathrm{H}$ NMR (DMSO- $\mathrm{d}_{6}$ ): 9.67 (s, $1 \mathrm{H}, \mathrm{NH}, \mathrm{D}_{2} \mathrm{O}$ exchangeable), $10.50 \quad(\mathrm{~s}, \mathrm{H}, \mathrm{OH}, \mathrm{D} 2 \mathrm{O}$ exchangeable), $1.98\left(\mathrm{~s}, 3 \mathrm{H}, \mathrm{CH}_{3}\right), 3.48(\mathrm{~s}, 3 \mathrm{H}$, $\left.-\mathrm{COCH}_{3}\right), 7.10-7.62(\mathrm{~m}, 3 \mathrm{H}, \mathrm{Ar}-\mathrm{H}), 4.92(\mathrm{~s}, 1 \mathrm{H}$, 4- $\mathrm{CH})$.

The partial purification of the asparaginase crude extract was obtained by ammonium sulfate $(70 \%)$ precipitation. The total protein was decreased from $1.41 \mathrm{mg}$ to $0.29 \mathrm{mg}$ in the ammonium sulfate precipitation step. The specific activity was increased to $0.751 \mathrm{U} / \mathrm{mg}$ and $9.83 \mathrm{U} / \mathrm{mg}$ after the S-sepharose gel filtration and DEAE cellulose column chromatography respectively (Table 2 ).

SDS-PAGE showed one band of enzyme with electrophoretic mobility of $9.8 \mathrm{~cm}$. By using different standard proteins of known molecular weights it was found that the apparent molecular weight of Erwinia carotovora (M.T.C.C.1428) asparaginase was $36.5 \mathrm{kDa}$ (Figure 2). The possible effect of all the eight DHP derivatives on asparaginase activity was initially assayed at fixed concentrations (0.085 $\mathrm{mM})$ of the substrate and at various concentrations $(1-30 \mu \mathrm{g} / \mathrm{ml})$ of DHP derivatives. Out of eight only two DHP derivatives were able to activate rate of asparagine hydrolysis by the enzyme (unpublished data for $\mathrm{P}_{3}-\mathrm{P}_{8}$ ). The maximal activation of asparaginase by $P_{1}$ was about 114.8 fold with an $E_{50}$ of $10 \mu \mathrm{g} / \mathrm{ml}$ and by $P_{2}$ was about 142 fold with an $E_{50}$ of $12 \mu \mathrm{g} / \mathrm{ml}$ (Figure 3, Table 4). This activation by DHP derivatives was completely reversible by dilution, did not affect the native molecular asparaginase structure that was confirmed by SDS -PAGE. Results of the kinetic parameters obtained for both the in the absence and in the presence DHP derivatives shown (Table 3 and Figure 4-6). The activation by DHP derivatives is revealed by an increase in the $\mathrm{V}_{\max }(1.75$ and 2.8 fold by $P_{1}$ and $P_{2}$ derivatives respectively) and decrease in the apparent $\mathrm{K}_{m}$ (from $0.087 \mathrm{mM}$ in the control to $0.080 \mathrm{mM}$ (Figure 3) and $0.071 \mathrm{mM}$ (Figure 4) in the presence of $\mathrm{P}_{1}$ and $\mathrm{P}_{2}$ derivatives respectively). With the purified enzyme obtained by ourselves was of two components one co-operative with lower $\mathrm{S}_{0.5}[0.045 \mathrm{mM} ; h$ (Hill coefficient) $=2.28$ Figure $7 \mathrm{a}]$ and $\mathrm{V}_{\text {max }}$ (2.84 I.U.) a second non cooperative component with higher $\mathrm{K}_{m}(0.080 \mathrm{mM})$ and $\mathrm{V}_{\max }(14.28 \mathrm{I} . \mathrm{U})$. In the presence of both the derivatives the saturation curve of asparaginase became hyperbolic $(h=1$, 
Figure $7 \mathrm{~b}, \mathrm{c})$ with an apparent $\mathrm{K}_{m}$ of 0.080 $\mathrm{mM}, 0.071 \mathrm{mM}$ and $\mathrm{V}_{\max } 25 \mathrm{IU}$ and $40 \mathrm{IU}$ respectively. The probable mechanism of activation of asparaginase in presence of derivative $P_{1}$ and $P_{2}$ may be due to the fact that the derivatives may bind to the site distant from the binding site especially with lysine residues or $\mathrm{N}$ terminal amino acid residues to form imine derivatives of asparaginase. Thereby it contributes to the proper orientation of the substrate and influence the rate of catalysis and substrate affinity. It has been reported that none of the lysine residues is located in the interior region of protein involved in substrate binding and catalysis [44].

Drug Prediction Analysis has shown that derivatives $P_{1}$ and $P_{2}$ provide important physiological properties for Asparaginase activation. The results suggested that activity of DHP derivatives depends upon the molecular weight and polarity of DHP derivatives. $P_{1}$ with $P a$ values of 0.42 and $P_{2}$ with 0.38 were found to be nearer to the standard $\mathrm{Pa}$ value 0.5 . The $\mathrm{P}_{1} \mathrm{MW}$ (391) was found to be more effective than $P_{2}$ MW (279.5). The Log $P$ values of $P_{1}$ (4.458) and $P_{2}$ (5.246) gives important information about its hydrophobicity and hydrophilicity and found to be effective as values are nearer to the standard.

\section{Conclusions}

The present investigation on the catalytic activity of L-asparaginase was prompted by our interest in the reactivity and hypersensitivity of L-asparaginase during therapeutic use. In the present study, the results clearly shows that derivatives $P_{1}$ and $\mathrm{P}_{2}$ behave like positive modulators of homotetrameric Erwinia asparaginase activity [45], acting through binding site that is different from the substrate binding site . Derivative $P_{1}$ and $P_{2}$ have no structural similarity to the true substrate of the enzyme and its activation is reversible, indicating that the effect may be due to a conformational change of the enzyme in presence of derivatives. Activation of $\mathrm{L}$ asparaginase by the derivative $P_{1}$ and $P_{2}$ is additive and this data reveals that two derivatives may interacting with two different sites of L-asparaginase. The $\left(\mathrm{P}_{2}\right)$ pyrimidinone derivative having chloro group was less effective in modulating the activity of $\mathrm{L}$ asparaginase as compared to the thioxo $\left(P_{1}\right)$ pyrimidine derivative. The structural changes of derivatives also affect catalytic activity of asparaginase and affinity for the substrate. The asparaginase injections has wide medicinal applications in treating Leukemia and other blood system tumors, as high catalytic activity of asparaginase in presence of derivative $P_{1}$ and $P_{2}$ would deplete the concentration of exogenous asparagine that is the prerequisite for growing tumor cells. The Asparaginase injections consist of reduced glutathione, water and supplementary materials [46]. In this aspect it would be feasible on biotechnological ground to provide it as supplementary material like other compounds. Such preparation process has the features of high stability and has well maintained structure and activity of asparaginase. In our laboratory studies we also found the potent inhibitory activity of $P_{1}$ and $\mathrm{P}_{2}$ derivative against the asparagine synthatase (unpublished data). The reported data opens the questions of possible role of DHP derivatives in combination chemotherapy protocols for ALL.

\section{Acknowledgements}

The first author acknowledges UGC, India, for awarding her the Non SAP-UGC meritorious fellowship. We are also thankful to the Director, School of Life Sciences, Swami Ramanand Teerth Marathwada University, Nanded and Director, IICT, Hyderabad for providing the necessary facilities.

\section{References}

[1] Kotzia G.A. and Labrou N.E. 2005) J. of Biotech. 119, 309-323.

[2] Howard J.B. and Carpenter F.H. (1972) J. Biol. Chem. 247, 1020-1030.

[3] Sanches M., Barbosa J.A.R.G, de Oliveira R.T., Abrahão Neto J.A. and Polikarpov I. (2003) Acta Crystallographica D59, 416-422.

[4] Kotzia G.A., Lappa K. and Labrou N.E. (2007) Biochem. Journal 404 (Pt 2), 337-343.

[5] Sansom C.E. and Jaskolski M. Structure, Dynamics and Electrostatics of the LAsparaginase Catalytic Centre: Implications for Reaction Mechanism (2000).

[6] Pinheiro J.P., Boos J. (2004) British J. of Haemato 125, 117-127.

[7] Rizzari C., Zucchetti M., Conter V., Diomede L., Bruno A., Gavazzi L., Paganini M., Sparano P., Lo Nigro L., Arico M., Milani M. and D'Inca1ci M. (2000) Annals of Oncology 11, 189193.

[8] Sokolov N.N., et al. (2005) Molecular Medicine, 1, 45-53.

[9] Cammack K.A., Marlborough D.I., and Miller D.S. (1972) Biochemistry Journal 126, 361-379. 
[10] Lisa T., et al. (2006) Cancer, 25(2) 306320.

[11] Mashburn L.T. and Wriston Jr. J.C. (1964) Archives of Biochemistry and Biophysics, 105, 450-452.

[12] Rossi F., Incorvaia C. and Mauro M. (2004) Recenti progressi in medicina 95(10), 476-481.

[13] Radulovic S., Golubovic Z., Jovanovic B. and Pejanovic J. (2004) Srp Arh Celok Lek 132, Suppl 1, 119-121.

[14] Chen C.H., et al. (2004) $J$ of the Formosan Medical Association, 103, $5,380-384$.

[15] Trivedi C.D. and Pitchumoni C. S. (2005) Journal of Clinical Gastroentrology, 39, 8, 709-716.

[16] Aoki C.A., Bowlus C.L. and Rossaro L. (2005) Digestive and Liver Disease, $37,3,206-210$.

[17] Imamura T., et al. (2005) Leukemia Lymphoma, 46(5), 729-737.

[18] Haddy T.B., et al. (2006) Pediatric Blood and Cancer, 46 (2), 258-261.

[19] Herna'ndez-Espinosa D., et al. (2006) American Journal of Pathology, 169, 142-153.

[20] Michael B., et al. (2006) Digestion, 74, 28, 1 -14.

[21] Goodsell D.S. (2005) Stem Cell, 123, 710-711.

[22] Verma N., et al. (2007) Critical Reviews in Biotechnology, 27(1), 45-62.

[23] Aghaiypour K., et al. (2001) Biochemistry 40, 5655-5664.

[24] Duvae M., et al. (2001) Blood, 999 (8), 2734-2739.

[25] Graham M.L. (2003) Advanced Drug Delivery Review, 55, 1293-1302.

[26] Rovnyk G.C., et al. (1992) Journal of Medicinal Chemistry 35 (17), 32543263.

[27] Hurst E.W. and Hull R. (1961) Journal of Medicinal Chemistry 3, 215 -229.

[28] Kath, C.L. John, J. Michael (2005) Pyrimidine derivatives for the treatment of abnormal cell growth, United States Patent, 7208499.
[29] Kidder G.W. and Dewey V.C. (1949) Journal of Biological Chemistry, 178, 383-387.

[30] Moravcova D., Havlicek L., Krystof V., Lenobel R., Strnad M. (2005) Pyrazolo [4,3-D] pyrimidines, processes for their preparation and methods for therapy, US Patent 20050080097.

[31] Rana K., et al. (2004) Indian Journal of Chemistry 43 B, 1553-1557.

[32] Nigel G.J., et al. (2006) Annual Review of Biochemistry, 75, 629-654.

[33] Borakotaku B. and Bezbarouah R.L. (2007) Folia Microbiologia, 47 (5), 473-476.

[34] Buck P.W., et al. (1971) J. of Gen Microbiol 65, 3 i.

[35] Kawaga, et.al., Roberts Hill, et.al., Lee, et.al. (1994) Method for the purification of $L$-asparaginase from Erwinia carotovora, U.S. Patent 5310670.

[36] Bradford M.M. (1976) Anal Biochem 72, 248-254.

[37] Ashraf A.El., Mohamed S. and Jehan M. (2004) J. of Biochem and Mol Biol, 37 (4), 387-393.

[38] Kappe C.O. (1993) Tetrahedron, 49, 6937- 6963.

[39] Skulnick H.I., Ludens J.H., Wendling M.G. (1986) J. of Med. Chem, 29, 1499-1504.

[40] Peterson R.E. and Ciegeler A. (1969) Applied Microbio, 18(1), 64-67.

[41] Peterson R.E. and Ciegeler A. (1969) Applied Microbiol, 17, (6), 929-930.

[42] Lowry O.H., et.al. (1951) J. of Biol Chem, 193, 265-275.

[43] Lineweaver H. and Burk D. (1934) J. of American Chem Soc., 56, 658-666.

[44] Sansom C.E. and Jaskolski M. (1996) Bioinformatics-structure17-21.

[45] Ho S.N., et al. (1989) Gene, 77, 51-59.

[46] Kislitsyn Yu.A., et al. (2006) Crystallo Reports, 51, (5) 811-816. 
Table 1- Activity and purity of L-asparaginase from E. carotovora obtained at different steps of Purification

\begin{tabular}{|c|c|c|c|c|c|c|}
\hline sample & $\begin{array}{l}\text { Volume } \\
\text { (ml) }\end{array}$ & $\begin{array}{l}\text { Activity } \\
(\mathrm{U} / \mathrm{ml})\end{array}$ & $\begin{array}{l}\text { Total activity } \\
\text { (units) }\end{array}$ & $\begin{array}{l}\text { Protein } \\
\text { concentration } \\
(\mathrm{mg} / \mathrm{ml})\end{array}$ & $\begin{array}{l}\text { Specific } \\
\text { activity } \\
(\mathrm{U} / \mathrm{mg})\end{array}$ & $\begin{array}{l}\text { Fold purification } \\
(\%)\end{array}$ \\
\hline Homogenate & 100 & 0.05 & 5.65 & 1.41 & 0.04 & ---- \\
\hline $\begin{array}{l}\text { S-sepharose } \\
\text { column }\end{array}$ & 30 & 0.63 & 19.1 & 0.85 & 0.75 & 18.9 \\
\hline CM cellulose & 30 & 1.07 & 32.3 & 0.78 & 1.3 & 34.7 \\
\hline $\begin{array}{l}\text { Ammonium } \\
\text { sulfate } \\
\text { precipitation }\end{array}$ & 25 & 1.84 & 46.1 & 0.54 & 3.4 & 85.9 \\
\hline DEAE cellulose & 15 & 2.85 & 42.7 & 0.29 & 9.8 & 247.6 \\
\hline
\end{tabular}

Table 2- Summary of the kinetic parameters of asparaginase in the absence and in the presence of DHP derivatives $P_{1}$ and $P_{2}$

\begin{tabular}{|l|l|l|l|l|}
\hline Addition & $\mathrm{K}_{m}(\mathrm{mM})$ & $\mathrm{V}_{\max }(\mathrm{IU})$ & $\mathrm{S}_{0.5}$ & Hill coefficient $(h)$ \\
\hline None & $0.087,0.160^{\mathrm{a}}$ & $14.28,7.20^{\mathrm{a}}, 2.84^{\mathrm{b}}$ & $0.045^{\mathrm{b}}$ & $2.28^{\mathrm{b}}$ \\
\hline $\mathrm{P}_{1}$ & 0.071 & 25.0 & & $0.988 \sim 1$ \\
\hline $\mathrm{P}_{2}$ & 0.080 & 40.0 & & $0.944 \sim 1$ \\
\hline
\end{tabular}

Kinetic parameters (mean \pm SD) are derived from the corresponding double-reciprocal plots by linear least squares fitting from three different experiments. ${ }^{a} V_{\max }$ and $\mathrm{K}_{m}$ values of second noncooperative component of the saturation curve for asparaginase activity. $b \mathrm{~V}_{\max }, \mathrm{S}_{0.5}$ and $h$ of the first component of the saturation curve for asparaginase activity.

Table 3- Additive effect of DHP derivatives $\mathrm{P}_{1}$ and $\mathrm{P}_{2}$ on the Erwinia carotovora asparaginase

\begin{tabular}{|c|c|c|}
\hline Additions & (final concentrations) & Fold activation \\
\hline P1 $(\mu \mathrm{g} / \mathrm{ml})$ & $\begin{array}{l}\mathrm{P} 2 \\
(\mu \mathrm{g} / \mathrm{ml})\end{array}$ & asparagine $(0.40 \mathrm{mM})$ \\
\hline ---- & ---- & 1 \\
\hline 5 & ---- & 36.3 \\
\hline 10 & ---- & 62.6 \\
\hline 20 & $-\cdots$ & 102.3 \\
\hline 30 & $-\cdots-$ & 110 \\
\hline 40 & ---- & 114 \\
\hline 50 & $\begin{array}{cc}--- \\
\end{array}$ & 108 \\
\hline--- & 10 & 97.7 \\
\hline---- & 20 & 103 \\
\hline ---- & 30 & 114 \\
\hline---- & 40 & 142 \\
\hline---- & 50 & 83.1 \\
\hline 10 & 10 & 100 \\
\hline 20 & 20 & 165 \\
\hline 30 & 30 & 153 \\
\hline 40 & 40 & 72.7 \\
\hline 50 & 50 & 68.6 \\
\hline
\end{tabular}

Enzyme activity determined at a fixed concentration of $0.40 \mathrm{mM}$ for asparagine. The activity in the absence of both derivatives was taken as 1 . The values presented (mean \pm SD from three different experiments) are the quotient of (activity observed at different concentration of Pyrimidine derivative) / (activity obtained in its absence). 


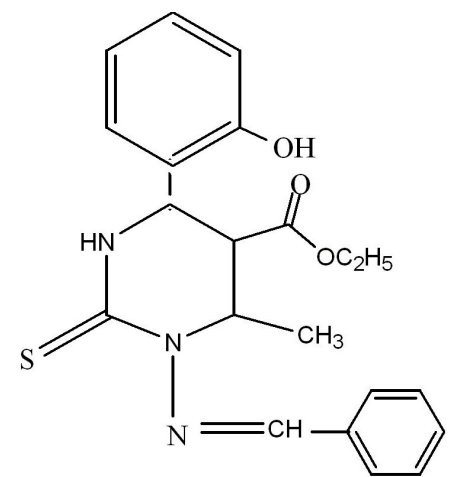

Scheme 1: 4-(2'-hydroxy phenyl ) - 6 -methyl - 2- thioxo-1- $N$ - benzilydene - 1,4 dihydropyrimidine - 5 carboxylic acid ethyl ester $\left(P_{1}\right)$<smiles>CC(=O)C1C(C)NC(=O)NC1c1cc(Cl)ccc1O</smiles>

Scheme 2: 4-(2'- hydroxy -5'- chlorophenyl) - 5 - acetyl -6 - methyl - 2- pyrimidinone (P2)

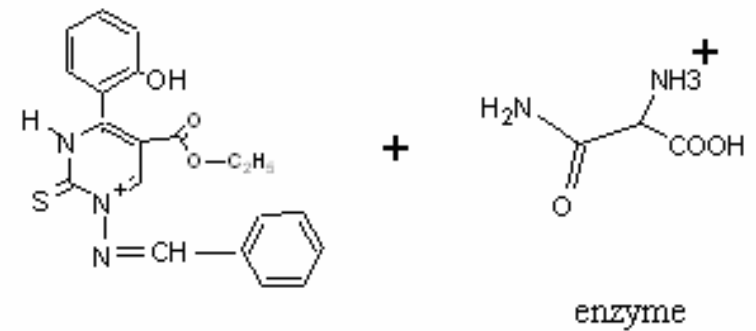

P1 derivative $-\mathrm{H}_{2} \mathrm{O}$<smiles>CCOC(=NC(=O)C(N)C(=O)[O-])C1=C(c2ccccc2O)N[C@H](S)[NH+](/N=C/c2ccccc2)C1</smiles>

imine derivative of P1

Scheme 3. Possible mechanism of P1 imine derivative formation 
<smiles></smiles>

P2 derivative<smiles>NC(=O)C([NH3+])C(=O)O</smiles>

enzyme<smiles>[Y]C(CO)CO</smiles><smiles>[CH][NH+]1CC(C(=O)OC)=C(c2cccc(Cl)c2)NC1O</smiles>

imine derivative of $\mathrm{P}_{2}$

Scheme 4: Possible mechanism P2 imine derivative formation
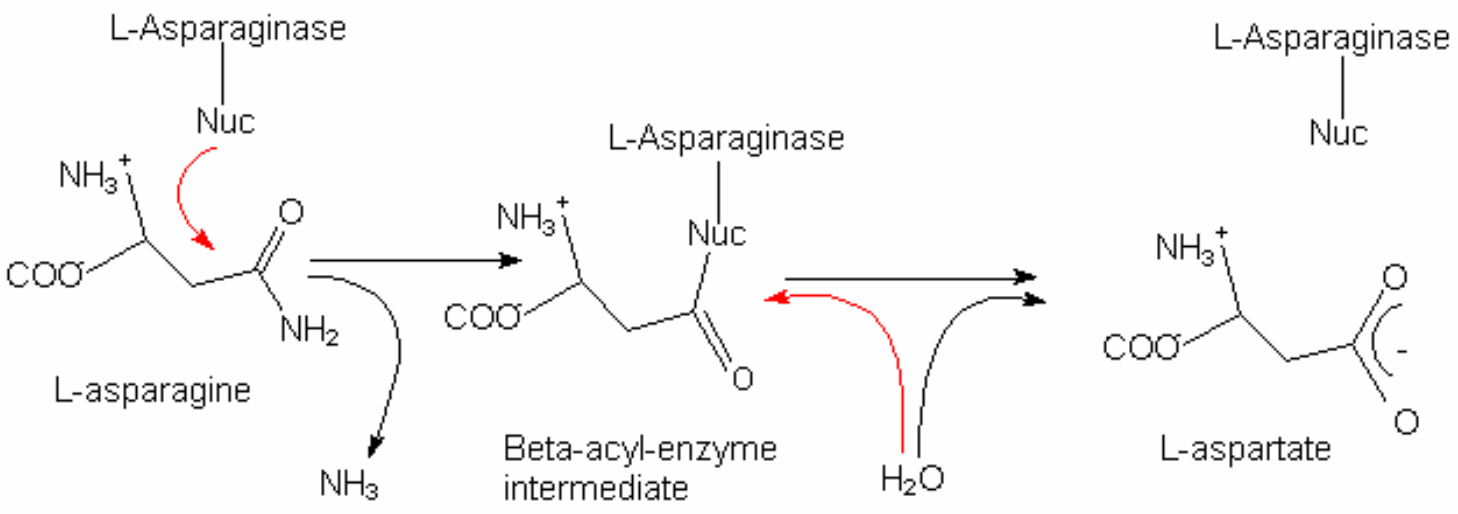

Figure 1. Reaction mechanism of L- asparaginase

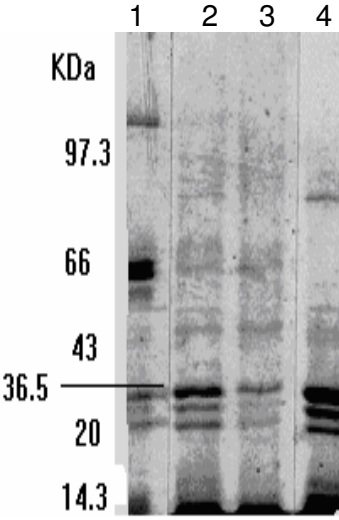

Figure 2. SDS PAGE of the purified L-asparaginase from the E. carotovora

Lane 1 molecular weight marker proteins, Lane 2 purified asparaginase,

Lane 3 purified asparaginase in presence of derivatives P1 and P2, Lane 4 crude preparation 


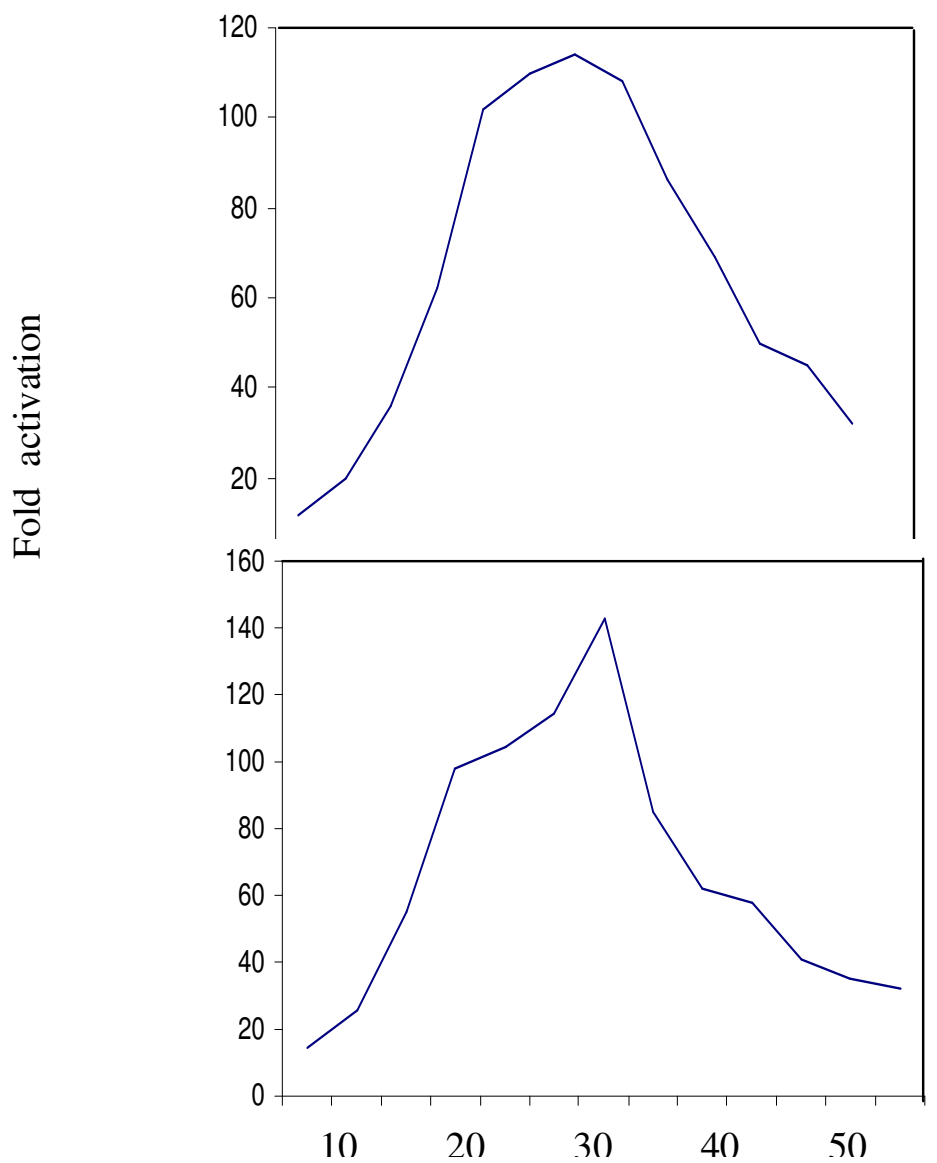

Figure 3. Effect of different amount of Pyrimidine derivative on the L-asparaginase catalytic activity

The activity observed at asparagine concentration of $0.085 \mathrm{mM}$ in the absence of pyrimidine derivative. The values presented (mean \pm SD from three different experiments) are (activity observed at different concentration of pyrimidine derivative)/(activity obtained in its absence). The half maximal dose for activation, Kai was obtained from double reciprocal plots of the results presented.

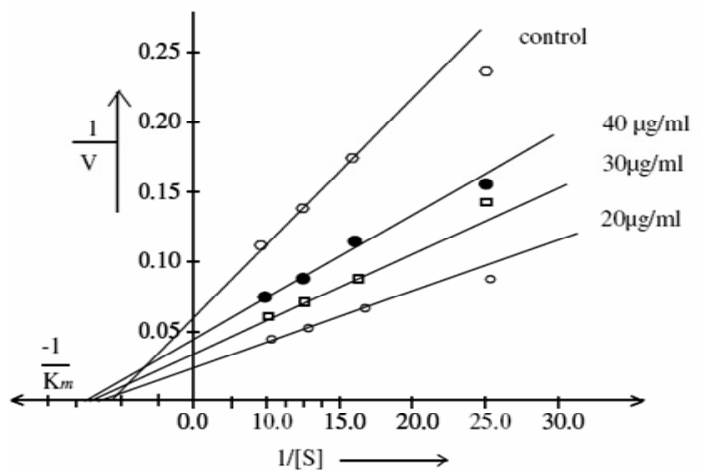

Figure 4. Lineweaver Burk plot of activation of Erwinia asparaginase by pyrimidine derivative P1 with asparagines concentration $(0.085 \mathrm{mM})$, enzyme $(3.4 \mathrm{U} / \mathrm{mg})$ in sodium borate buffer $(100 \mathrm{mM}, \mathrm{pH} 8.5)$ to a total volume of 3.05 $\mathrm{ml}$. 


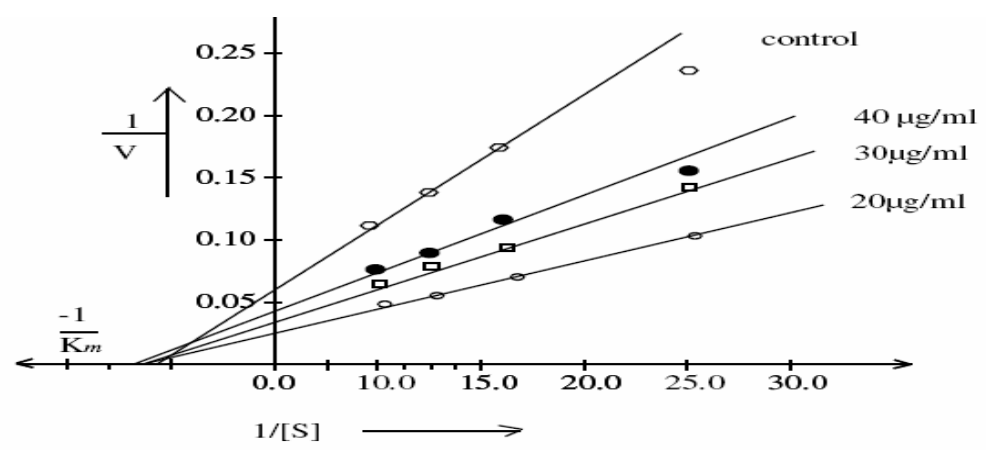

Figure 5. Lineweaver Burk plot of activation of Erwinia asparaginase by pyrimidine derivative P2 with asparagines concentration $(0.085 \mathrm{mM})$, enzyme $(3.4 \mathrm{U} / \mathrm{mg})$ in sodium borate buffer $(100 \mathrm{mM}, \mathrm{pH} 8.5)$ to a total volume of 3.05 $\mathrm{ml}$.

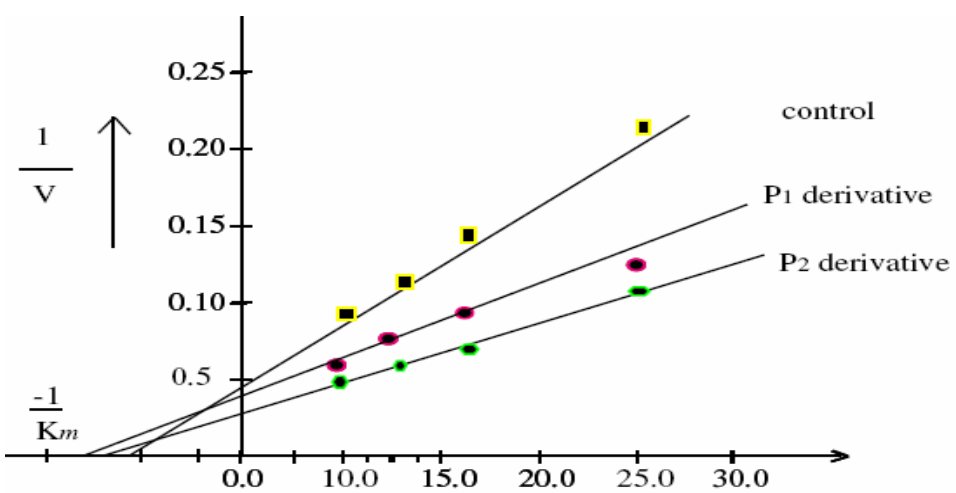

Figure 6. Lineweaver Burk plot of activation of Erwinia asparaginase by pyrimidine derivative $\mathrm{P} 1$ and $\mathrm{P} 2$ with asparagines concentration $(0.085 \mathrm{mM})$, enzyme $(3.4 \mathrm{U} / \mathrm{mg})$ in sodium borate buffer $(100 \mathrm{mM}, \mathrm{pH} 8.5)$ to a total volume of $3.05 \mathrm{ml}$.
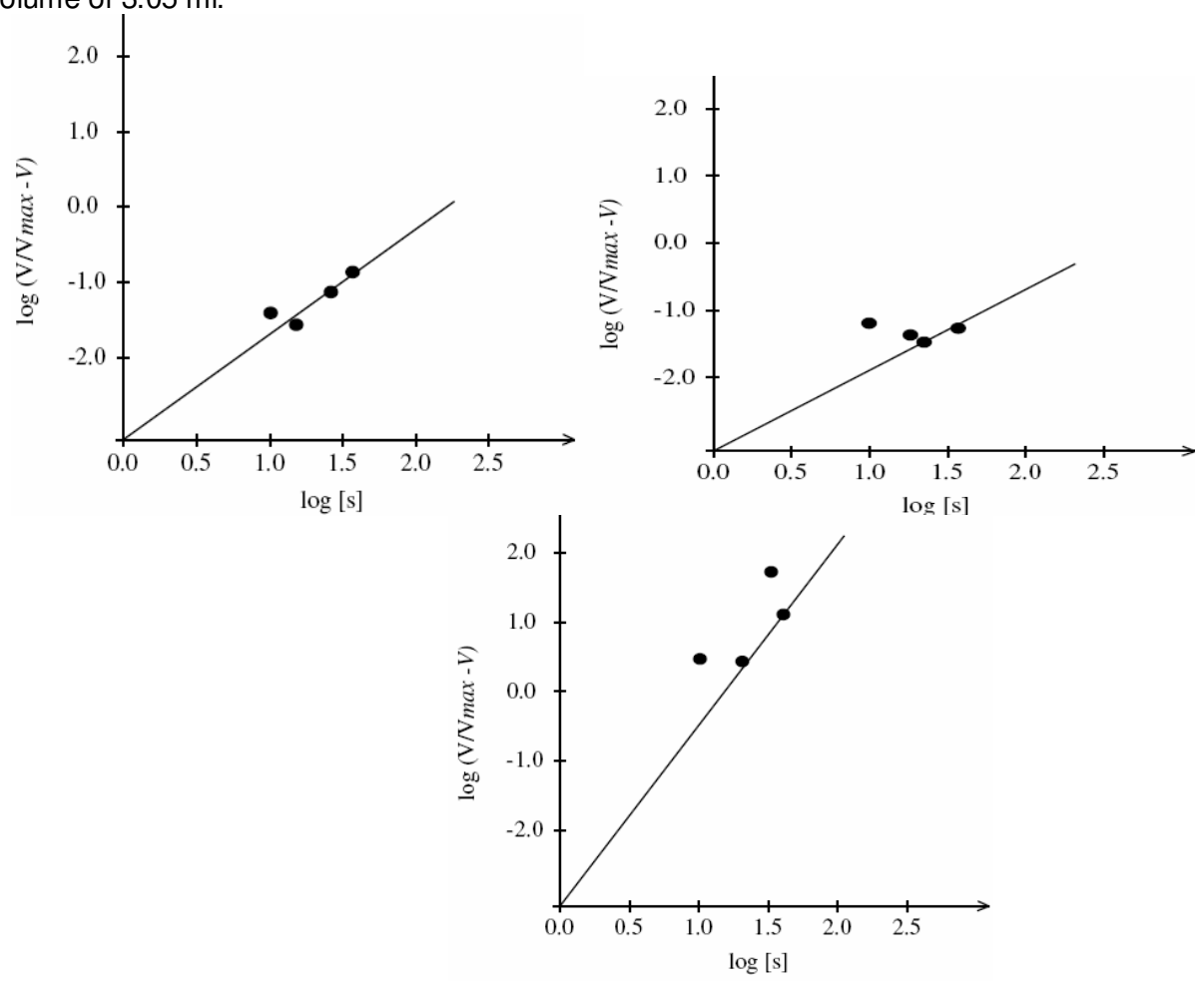

Figure $7 \mathrm{a}, \mathrm{b}$ and $\mathrm{c}$. Hill plot of asparaginase catalytic activity in presence and absence of dihydropyrimidine derivatives with asparagine concentration $(0.085 \mathrm{mM})$, enzyme $(3.4 \mathrm{U} / \mathrm{mg})$ in sodium borate buffer $(100 \mathrm{mM}, \mathrm{pH}$ $8.5)$ to a total volume of $3.05 \mathrm{ml}$. 